\title{
Vasopressin-Induced Constriction of the Isolated Rat Occipital Artery is Segment Dependent
}

\author{
Stephen P. Chelko ${ }^{a}$ Chad W. Schmiedt $^{\mathrm{b}}$ Tristan H. Lewis ${ }^{c}$ Stephen J. Lewis $^{\mathrm{d}}$ \\ Tom P. Robertson ${ }^{c}$

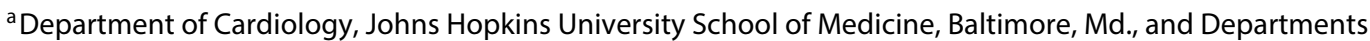 \\ of b'Small Animal Medicine and Surgery, and 'Physiology and Pharmacology, College of Veterinary Medicine, \\ The University of Georgia, Athens, Ga., and d Department of Pediatrics, School of Medicine, Case Western Reserve \\ University, Cleveland, Ohio, USA
}

\section{Key Words}

Arginine vasopressin - Nodose ganglia - Occipital artery .

Vascular reactivity

\begin{abstract}
Background: Circulating factors delivered to the nodose ganglion (NG) by the occipital artery (OA) have been shown to affect vagal afferent activity, and thus the contractile state of the OA may influence blood flow to the NG. Methods: OA were isolated and bisected into proximal and distal segments relative to the external carotid artery. Results: Bisection highlighted stark differences between maximal contractile responses and OA sensitivity. Specifically, maximum responses to vasopressin and the $\mathrm{V}_{1}$ receptor agonist were significantly higher in distal than proximal segments. Distal segments were significantly more sensitive to 5-hydroxytryptamine $(5-\mathrm{HT})$ and the $5-\mathrm{HT}_{2}$ receptor agonist than proximal segments. Angiotensin II (AT) $)_{2} \mathrm{~V}_{2}$ and $5-\mathrm{HT}_{1 \mathrm{~B} / 1 \mathrm{D}}$ receptor agonists did not elicit vascular responses. Additionally, $\mathrm{AT}_{1}$ receptor agonists elicited mild, yet not significantly different maximal responses between segments. Conclusion: The results of this study are consistent with contractile properties of rat $\mathrm{OA}$ being mediated via $\mathrm{AT}_{1}, \mathrm{~V}_{1}$ and $5-\mathrm{HT}_{2}$ recep-
\end{abstract}

\section{KARGER}

E-Mail karger@karger.com

www.karger.com/jvr tors and dependent upon the OA segment. Furthermore, vasopressin-induced constriction of the $O A$, regardless of a bolus dose or a first and second concentration-response curve, retained this unique segmental difference. We hypothesize that these segmental differences may be important in the regulation of blood flow through the $O A$ in health and disease.

c) 2013 S. Karger AG, Basel

\section{Introduction}

The occipital arteries (OA) arise from the external carotid arteries (ECA), proximal to the bifurcation of the common carotid arteries into the internal carotid arteries (ICA) and ECA. The OA supply blood to the occipital lobe and external cranium, muscles of the sternomastoid region and cell bodies of the petrosal (PG) and nodose ganglia (NG) [1]. Whereas blood supply to the PG and NG is provided by both the ICA and OA, recent research has demonstrated that there are differences in the permeability of the blood-ganglion barrier at the OA-NG complex compared to the ICA-NG complex $[1,2]$. Specifically, Lacolley et al. [1] demonstrated that the small mo- 
lecular weight (MW) tracer BB9 (Basic Blue 9, MW = 374) entered NG cell bodies $30 \mathrm{~min}$ after injection into the jugular vein of rats with patent $O A$. In contrast, there was no BB9 staining of NG cell bodies in rats with ipsilateral OA ligations. Therefore, sustained increases in blood-borne factors $\left(\mathrm{O}_{2}\right.$, glucose, $\left.\leq 1,000 \mathrm{MW}\right)$ delivered to the $\mathrm{NG}$ via the OA may alter baroreflex function.

As such, increased acute constriction of the OA via angiotensin (AT) II may lead to decreased delivery of vital factors to the NG and surrounding tissue. Conversely, chronic AT tachyphylaxis due to high AT plasma levels could increase flow through the OA. Therefore, the contractile properties of the $\mathrm{OA}$ are of equal importance. There are few studies currently that detail the contractile properties of isolated OA. Verheggen et al. [3] extensively detailed functional 5-hydroxytryptamine (5-HT) receptors in OA from human patients and demonstrated that 5-HT-induced constriction of the $\mathrm{OA}$ is mediated via $5-\mathrm{HT}_{1 \mathrm{~B}}$ and $5-\mathrm{HT}_{2 \mathrm{~A}}$ receptors at low and high concentrations, respectively. However, these arteries were harvested from anesthetized individuals with disease, such as brain tumors and aneurysms [3]. It should be noted that anesthetics, both inhaled and intravenous, have demonstrated to have significant effects on vasoreactivity and thus should be taken into consideration when analyzing such responses $[4,5]$.

Therefore, the aim of this study was to provide an initial characterization of the contractile effects of three physiologically relevant agonists (AT, vasopressin and 5-HT) on OA isolated from healthy male Sprague-Dawley rats with no drug treatment or anesthetic, intravenous or inhaled, prior to tissue harvesting. As such, it is our hypothesis that $\mathrm{OA}$ will constrict to $5-\mathrm{HT}_{1 / 2}, \mathrm{AT}_{1}$ and $\mathrm{V}_{1}$ receptor agonists and dilate to $\mathrm{AT}_{2}$ and $\mathrm{V}_{2}$ receptor agonists. Additionally, $\mathrm{AT}_{1}, \mathrm{~V}_{1}$ and $5-\mathrm{HT}_{1 / 2}$ tachyphylaxis, as demonstrated through a second concentration-response curve, will highlight the potential adverse effects of increased plasma concentrations of AT, vasopressin and 5-HT on arterial tone, as seen in hypertension and diabetes.

\section{Materials and Methods}

This investigation conforms to the Guide for the Care and Use of Laboratory Animals published by the National Institutes of Health (NIH Publication No. 85-23, revised 1996) and all protocols were approved by The University of Georgia Institutional Animal Care and Use Committee.

OA Isolation and Small Vessel Myography

Male Sprague-Dawley rats (350-380 g) were euthanized by decapitation and the heads immediately placed in ice-cold physiological saline solution (PSS) containing (in $\mathrm{mM}$ ): $\mathrm{NaCl} 118$,
$\mathrm{NaHCO}_{3} 24, \mathrm{KCl} 4$, glucose 5.6, $\mathrm{MgSO}_{4} 1, \mathrm{NaH}_{2} \mathrm{PO}_{4} 0.435$ and $\mathrm{CaCl}_{2}$ 1.8. On the stage of a high-powered dissecting microscope, OA (250-400 $\mu \mathrm{m}$ internal diameter; 3.5-4.5 $\mathrm{mm}$ in length) were isolated and bisected into proximal and distal segments (each $\sim 2 \mathrm{~mm}$ long) and mounted separately on small vessel myographs (model 500A; Danish Myo Technology, Denmark). After equilibrating for $30 \mathrm{~min}$ in PSS gassed with $12 \%$ $\mathrm{O}_{2}, 5 \% \mathrm{CO}_{2}$ and $83 \% \mathrm{~N}_{2}\left(\mathrm{pH} 7.4,37^{\circ} \mathrm{C}\right)$, OA were stretched using the methods described by Mulvany and Halpern [6] for systemic arteries. The maximum responses of OA segments to a depolarizing stimulus were then established by exposing them to 80 $\mathrm{mM} \mathrm{K}^{+}$(KPSS; isotonic replacement of $\mathrm{Na}^{+}$by $\mathrm{K}^{+}$; exposed $3 \times 2$ $\mathrm{min}, 15-20 \mathrm{~min}$ apart), as described previously for other vessel types [7].

\section{Experimental Protocols}

Concentration-response curves for AT, vasopressin, 5-HT and agonists for specific receptor subtypes were established in OA segments in the absence or presence of receptor antagonists. In experiments where antagonists were used, the antagonists were added to the bathing solution 15 min prior to the first agonist concentration. Upon OA isolation (2 OA per rat), each OA was separated to an individual myograph and bisected, such that each bath contained a distal and proximal segment. Bisection of the OA was confirmed by viewing the sections side by side under the microscope to ensure sections were of equal length. Following the third KPPS exposure and a washing step with PSS, one OA (distal and proximal segments) served as a control while the other (distal and proximal segments) contained the pharmacologically appropriate antagonist, and a single concentration-response curve was performed. Based on preliminary experiments, concentration-response curves to the $\mathrm{AT}_{2}$ receptor agonist, CPG-42112A, the $\mathrm{V}_{2}$ receptor agonist, desmopressin, and the $5-\mathrm{HT}_{1 \mathrm{~B} / 1 \mathrm{D}}$ receptor agonist, sumatriptan, were performed on OA with one bath serving as a control while the other bath contained OA preconstricted with prostaglandin $\mathrm{F}_{2 \alpha}\left(\mathrm{PGF}_{2 \alpha}\right)$.

To ensure that our techniques do not damage the OA endothelium, we assessed the dilator effect of acetylcholine ( $1 \mathrm{nM}$ to $10 \mu \mathrm{M})$ in OA preconstricted with 5-HT $(10 \mu \mathrm{M})$. Acetylcholine-induced dilation in distal and proximal OA segments was similar in magnitude (distal segment: $82.4 \pm 4.5 \%$ maximal dilation and proximal segment: $84.3 \pm 4.4 \%$ maximal dilation, $\mathrm{n}=8$ for both).

\section{Agonists and Antagonists}

$\left[\mathrm{Val}^{5}\right]$-AT II acetate salt hydrate $\left(\mathrm{AT}_{1}\right.$ receptor agonist), CPG$42112 \mathrm{~A}\left(\mathrm{AT}_{2}\right.$ receptor agonist), losartan potassium ( $\mathrm{AT}_{1}$ receptor antagonist), $\left[\mathrm{Arg}^{8}\right]$-vasopressin acetate salt (vasopressin receptor agonist), [deamino-Cys ${ }^{1}, \mathrm{D}-\mathrm{Arg}^{8}$ ]-vasopressin acetate salt hydrate $\left(\mathrm{V}_{2}\right.$ receptor agonist, desmopressin), $[\beta$-mercapto- $\beta, \beta$-cyclopenta methylenepropionyl ${ }^{1}, O$-me-Tyr $\left.{ }^{2}, \mathrm{Arg}^{8}\right]$-vasopressin $\left[\mathrm{V}_{1}\right.$ receptor antagonist, $\left.\mathrm{d}\left(\mathrm{CH}_{2}\right)_{5} \mathrm{Tyr}(\mathrm{Me}) \mathrm{AVP}\right], 5-\mathrm{HT}$ hydrochloride, $(R)-(+)$ 8-hydroxy-DPAT hydrobromide (8-OH-DPAT; $5-\mathrm{HT}_{1 \mathrm{~A}}$ receptor agonist), $\alpha-\mathrm{CH}_{3}-5-\mathrm{HT}$ maleate salt (5- $\mathrm{HT}_{2}$ receptor agonist), NAN-190 hydrobromide (5- $\mathrm{HT}_{1 \mathrm{~A}}$ receptor antagonist), sumatriptan succinate $\left(5-\mathrm{HT}_{1 \mathrm{~B} / 1 \mathrm{D}}\right.$ receptor agonist) and ketanserin tartrate salt $\left(5-\mathrm{HT}_{2}\right.$ receptor antagonist) were purchased from Sigma Chemical Co. (St. Louis, Mo., USA); AT II was purchased from the American Peptide Co. (Sunnyvale, Calif., USA), and ( $\mathrm{Phe}^{2}, \mathrm{Ile}^{3}$, $\left.\mathrm{Orn}^{8}\right)$-vasopressin $\left(\mathrm{V}_{1}\right.$ receptor agonist) was purchased from Bachem (Torrance, Calif., USA). 
Statistical Analysis

Contractile responses were expressed as a percentage of the maximal contractile response to KPSS $\left(\% \mathrm{~T}_{\mathrm{K}}\right)$ for each vessel. Data are presented as means \pm SEM. Maximal contractile responses $\left(\mathrm{E}_{\max }\right)$ for control distal versus control proximal segments, control distal segments versus distal + antagonist segments, and control proximal segments versus proximal + antagonist segments were analyzed by 2 -way analysis of variance with post hoc analysis using the Bonferroni correction for multiple comparisons (GraphPad Prism). Vasoconstrictor sensitivity $\left(\mathrm{EC}_{50}\right)$ was calculated using nonlinear regression analysis, where $\mathrm{EC}_{50}$ is the concentration of agonist which elicits half the maximal response ( $\mathrm{E}_{\max }$; varied upon agonist) from baseline $\left(0 \% \mathrm{E}_{\max }\right.$; for all agonists), and differences between $\mathrm{EC}_{50}$ values were determined by Student's modified $t$ test. A value of $\mathrm{p}<0.05$ was deemed to be significant.

\section{Results}

\section{OA Responses to AT II}

AT II ( $100 \mathrm{pM}$ to $300 \mathrm{nM}$ ) elicited contractions in proximal and distal OA segments in a concentration-dependent manner (fig. 1a). Maximal contractile responses to AT were not significantly different between distal and proximal OA segments (distal segment $\mathrm{E}_{\max }: 14.1 \pm 2.4 \%$ $\mathrm{T}_{\mathrm{K}}$ and proximal segment $\mathrm{E}_{\max }: 19.6 \pm 3.4 \% \mathrm{~T}_{\mathrm{K}}, \mathrm{n}=9$ for both; table 1). Similar results were found for the $\mathrm{AT}_{1}$ receptor agonist, $\mathrm{Val}^{5}$-AT II (100 pM to $300 \mathrm{nM}$; online suppl. fig. 1A; for all online suppl. material, see www.karger. com/doi/10.1159/000355265; distal segment $\mathrm{E}_{\max }: 13.5 \pm$ $2.6 \% \mathrm{~T}_{\mathrm{K}}$ and proximal segment $\mathrm{E}_{\max }: 14.0 \pm 2.1 \% \mathrm{~T}_{\mathrm{K}}, \mathrm{n}=$ 9 for both; table 1). Distal OA segments were significantly more sensitive to AT $\left(\mathrm{EC}_{50}: 3.1 \pm 1.5 \mathrm{nM}, \mathrm{n}=9\right)$ than proximal segments $\left(\mathrm{EC}_{50}: 8.2 \pm 1.4 \mathrm{nM}, \mathrm{n}=9\right.$; table 1$)$, though there was no significant difference in OA sensitivity to $\mathrm{Val}^{5}$-AT II between segments. Addition of $1 \mu \mathrm{M}$ losartan $\left(\mathrm{AT}_{1}\right.$ receptor antagonist) completely inhibited the contractile effects of AT and $\mathrm{Val}^{5}$-AT II in both proximal and distal OA segments (table 1). The $\mathrm{AT}_{2}$ receptor agonist CPG-42112A (100 pM to $100 \mathrm{nM}$ ) did not elicit any contractile responses in proximal and distal OA segments and did not elicit dilation in OA segments preconstricted to $\sim 40 \% \mathrm{~T}_{\mathrm{K}}$ with $\mathrm{PGF}_{2 \alpha}$ (data not shown). Since tachyphylaxis is often observed to AT II in isolated arteries due to rapid $\mathrm{AT}$ II $\mathrm{AT}_{1}$ receptor internalization $[8,9]$, we also determined the effects of a bolus concentration of AT II (100 nM) on OA segments. As expected, the maximum response to AT II was significantly higher than that observed during concentration-response curves (distal segments: bolus $\mathrm{E}_{\max }: 47.5 \pm 8.8 \% \mathrm{~T}_{\mathrm{K}}, \mathrm{n}=4$, vs. concentration response $\mathrm{E}_{\max }: 14.1 \pm 2.4 \% \mathrm{~T}_{\mathrm{K}}$, and proximal seg- ments: bolus $\mathrm{E}_{\max }: 39.1 \pm 11.2 \% \mathrm{~T}_{\mathrm{K}}, \mathrm{n}=4$, vs. concentration response $\mathrm{E}_{\max }: 19.6 \pm 3.4 \% \mathrm{~T}_{\mathrm{K}} ; \mathrm{p}<0.05$; online suppl. table 1).

\section{OA Responses to Arginine Vasopressin}

Cumulative addition of vasopressin $(100 \mathrm{pM}$ to $1 \mu \mathrm{M})$ to the bathing solution elicited contractions in both proximal and distal OA segments. However, distal segments constricted to a significantly higher degree than proximal segments when exposed to vasopressin (fig. 1b; distal segment $\mathrm{E}_{\max }: 74.2 \pm 6.8 \% \mathrm{~T}_{\mathrm{K}}, \mathrm{n}=11$, and proximal segment $\mathrm{E}_{\text {max }}: 29.7 \pm 8.5 \% \mathrm{~T}_{\mathrm{K}}, \mathrm{n}=10$; table 2 ). This was also the case for the $\mathrm{V}_{1}$ receptor agonist, $\left(\mathrm{Phe}^{2}\right.$, $\mathrm{Ile}^{3}$, $\left.\mathrm{Orn}^{8}\right)$-vasopressin (100 pM to $1 \mu \mathrm{M}$; distal segment $\mathrm{E}_{\max }$ : $66.6 \pm 10.7 \% \mathrm{~T}_{\mathrm{K}}$ and proximal segment $\mathrm{E}_{\max }: 26.7 \pm 3.8 \%$ $\mathrm{T}_{\mathrm{K}}, \mathrm{n}=10$ for both; online suppl. fig. 1B). There was no difference in OA sensitivity to vasopressin between segments, however distal segments were significantly more sensitive to $\left(\mathrm{Phe}^{2}, \mathrm{Ile}^{3}, \mathrm{Orn}^{8}\right)$-vasopressin $\left(\mathrm{EC}_{50}: 24.2 \pm\right.$ $1.4 \mathrm{nM}, \mathrm{n}=10)$ than proximal segments $\left(\mathrm{EC}_{50}: 36.7 \pm 1.3\right.$ $\mathrm{nM}, \mathrm{n}=10$; table 2). Addition of $10 \mathrm{nM} \mathrm{d}\left(\mathrm{CH}_{2}\right)_{5} \mathrm{Tyr}(\mathrm{Me})$ $\mathrm{AVP}\left(\mathrm{V}_{1}\right.$ receptor antagonist) completely inhibited the contractile effects of vasopressin and $\left(\mathrm{Phe}^{2}, \mathrm{Ile}^{3}, \mathrm{Orn}^{8}\right)$ vasopressin in both $\mathrm{OA}$ segments (table 2). The $\mathrm{V}_{2}$ receptor agonist, desmopressin (100 pM to $100 \mathrm{nM})$, did not elicit any change in tone (constriction and/or dilation) in either segment of the OA (data not shown). Additionally, vasopressin demonstrated tachyphylaxis in control and denuded aortic rings upon subsequent administration of vasopressin [10]. Therefore, we determined the effects of a bolus dose of vasopressin (100 nM) on separate OA preparations as well as two vasopressin concentration-response curves (100 pM to $1 \mu \mathrm{M} ; 25 \mathrm{~min}$ apart) in additional OA preparations. A bolus dose of vasopressin elicited almost identical and statistically different responses between segments (distal segment $\mathrm{E}_{\text {max }}$ : $61.4 \pm 2.3 \% \mathrm{~T}_{\mathrm{K}}$ and proximal segment $\mathrm{E}_{\text {max }}: 25.8 \pm 1.02 \%$ $\mathrm{T}_{\mathrm{K}}, \mathrm{n}=5$ for both; online suppl. table 1). However, in experiments where a second concentration-response curve was performed, vasopressin elicited reduced maximal responses at both segments compared with initial response curves (distal segment $\mathrm{E}_{\mathrm{max}}: 40.5 \pm 3.2 \% \mathrm{~T}_{\mathrm{K}}$ and proximal segment $\mathrm{E}_{\text {max }}: 10.4 \pm 1.14 \% \mathrm{~T}_{\mathrm{K}}, \mathrm{n}=5$ for both).

\section{OA Responses to 5-HT}

The proximal and distal segments of the OA contracted robustly when 5 -HT ( $1 \mathrm{nM}$ to $100 \mu \mathrm{M})$ was added cumulatively to the bathing solution (fig. 1c). Maximal contractile responses to $5-\mathrm{HT}$ were not significantly different 
Fig. 1. Mean \pm SEM responses of proximal $(\boldsymbol{\square})$ and distal $(\boldsymbol{\Delta})$ segments of the OA to AT (a), vasopressin (b) and 5-HT (c). ${ }^{*} \mathrm{p}<$ 0.05 .

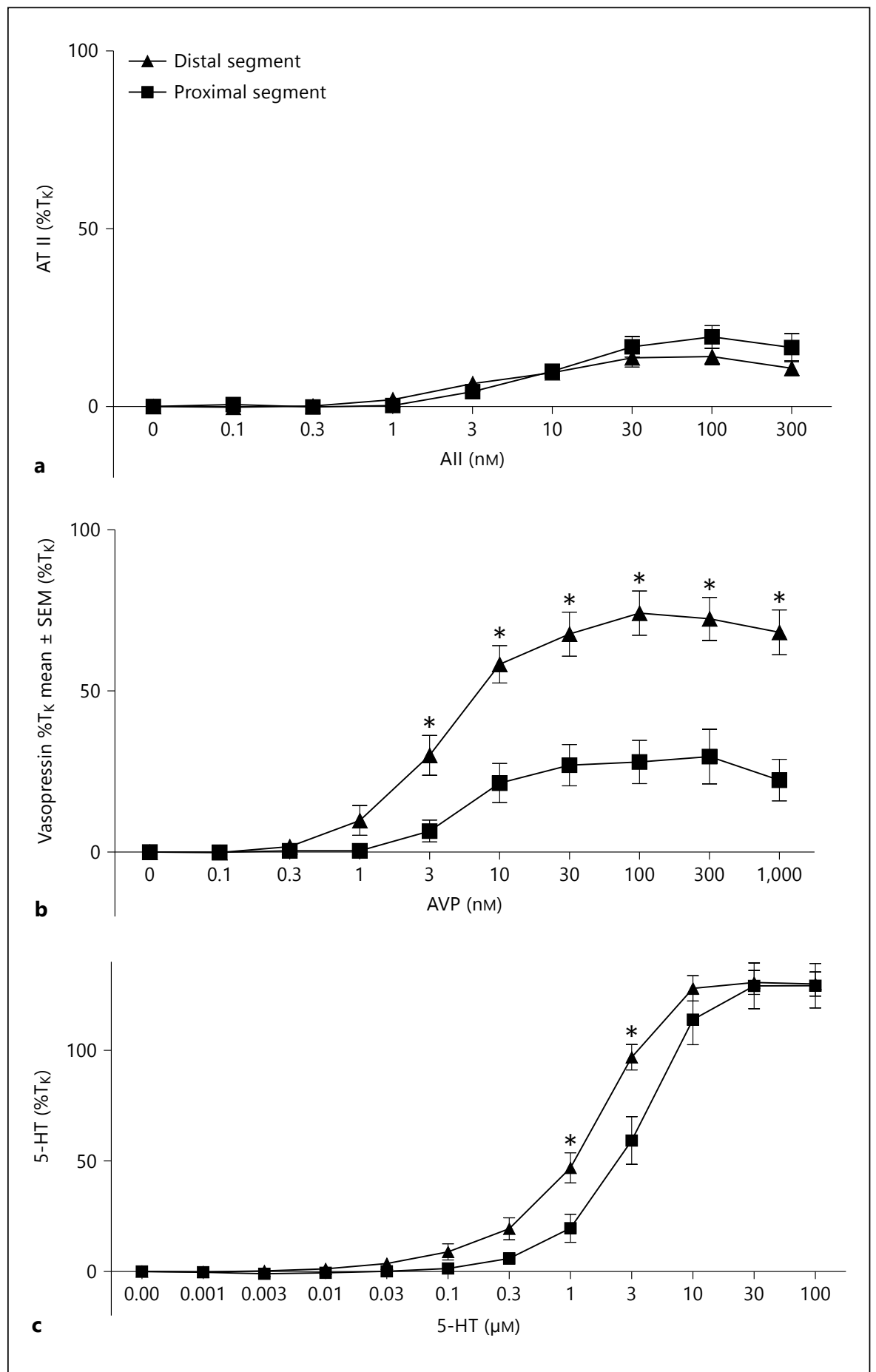

between OA segment types (distal segment $\mathrm{E}_{\max }: 130.7 \pm$ $5.7 \% \mathrm{~T}_{\mathrm{K}}$ and proximal segment $\mathrm{E}_{\max }: 129.2 \pm 10.5 \% \mathrm{~T}_{\mathrm{K}}$, $\mathrm{n}=11$ for both; table 3 ). However, when the $5-\mathrm{HT}_{2}$ receptor agonist $\alpha-\mathrm{CH}_{3}-5-\mathrm{HT}(1 \mathrm{nM}$ to $100 \mu \mathrm{M})$ was added to the bathing solution, distal segments constricted to a sig- nificantly higher degree than proximal segments (distal segment $\mathrm{E}_{\max }: 108.1 \pm 3.7 \% \mathrm{~T}_{\mathrm{K}}, \mathrm{n}=21$, and proximal segment $\mathrm{E}_{\max }: 82.0 \pm 3.9 \% \mathrm{~T}_{\mathrm{K}}, \mathrm{n}=16$; online suppl. fig. $1 \mathrm{C}$ ). Distal segments were significantly more sensitive than proximal segments to $5-\mathrm{HT}$ and $\mathrm{a}-\mathrm{CH}_{3}-5-\mathrm{HT}$ (table 3 ). 
Table 1. Contractile effects of AT and $\mathrm{Val}^{5}-\mathrm{AT}$ on the proximal and distal OA segments

\begin{tabular}{|c|c|c|c|c|}
\hline Segment & $\mathrm{AT}$ & $\mathrm{AT}_{1}$ & $\mathrm{AT}+$ losartan & $\mathrm{AT}_{1}+$ losartan \\
\hline \multicolumn{5}{|l|}{ Proximal } \\
\hline $\mathrm{E}_{\max }, \% \mathrm{~T}_{\mathrm{K}}$ & $19.6 \pm 3.4(n=9)$ & $14.0 \pm 2.1(n=9)$ & $0.0 \pm 0.6^{b}(\mathrm{n}=9)$ & $0.1 \pm 0.2^{b}(\mathrm{n}=9)$ \\
\hline $\mathrm{EC}_{50}, \mathrm{nM}$ & $8.2 \pm 1.4$ & $4.7 \pm 1.3$ & NA & $\mathrm{NA}$ \\
\hline \multicolumn{5}{|l|}{ Distal } \\
\hline $\mathrm{E}_{\max }, \% \mathrm{~T}_{\mathrm{K}}$ & $14.1 \pm 2.4(\mathrm{n}=9)$ & $13.5 \pm 2.6(n=9)$ & $0.3 \pm 0.5^{\mathrm{b}}(\mathrm{n}=9)$ & $0.0 \pm 0.4^{\mathrm{b}}(\mathrm{n}=9)$ \\
\hline $\mathrm{EC}_{50}, \mathrm{nM}$ & $3.1 \pm 1.5^{\mathrm{a}}$ & $4.2 \pm 1.4$ & NA & NA \\
\hline
\end{tabular}

Data are presented as means \pm SEM. ${ }^{\mathrm{a}} \mathrm{p}<0.05$ between segment type. ${ }^{\mathrm{b}} \mathrm{p}<0.05$ between agonists in specific OA segment. NA $=$ Not applicable.

Table 2. Contractile effects of vasopressin and $\left(\mathrm{Phe}^{2}, \mathrm{Ile}^{3}, \mathrm{Orn}^{8}\right)$-vasopressin on the proximal and distal OA segments

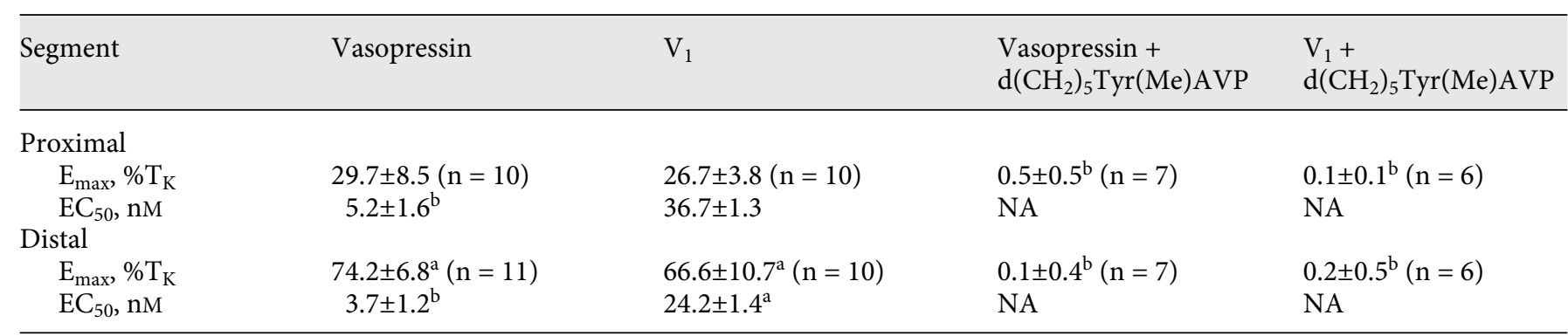

Data are presented as means \pm SEM. ${ }^{\mathrm{a}} \mathrm{p}<0.05$ between segment type. ${ }^{\mathrm{b}} \mathrm{p}<0.05$ between agonists in specific OA segment. NA $=$ Not applicable.

Table 3. Contractile effects of $5-\mathrm{HT}, \alpha-\mathrm{CH}_{3}-5-\mathrm{HT}$, and $8-\mathrm{OH}-\mathrm{DPAT}$ on the proximal and distal OA segments

\begin{tabular}{|c|c|c|c|c|c|c|}
\hline Segment & $5-\mathrm{HT}$ & $5-\mathrm{HT}_{2}$ & $5-\mathrm{HT}_{1 \mathrm{~A}}$ & $\begin{array}{l}5-\mathrm{HT}+ \\
\text { ketanserin }\end{array}$ & $\begin{array}{l}5-\mathrm{HT}_{2}+ \\
\text { ketanserin }\end{array}$ & $\begin{array}{l}5-\mathrm{HT}_{1 \mathrm{~A}}+ \\
\text { ketanserin }\end{array}$ \\
\hline \multicolumn{7}{|l|}{ Proximal } \\
\hline $\mathrm{E}_{\max }, \% \mathrm{~T}_{\mathrm{K}}$ & $129.2 \pm 10.5(n=11)$ & $82.0 \pm 3.9(\mathrm{n}=16)$ & $5.7 \pm 1.4^{\mathrm{b}}(\mathrm{n}=15)$ & $0.9 \pm 0.2^{\mathrm{b}}(\mathrm{n}=7)$ & $1.5 \pm 0.7^{b}(\mathrm{n}=8)$ & $0.1 \pm 0.7^{b}(\mathrm{n}=7)$ \\
\hline $\mathrm{EC}_{50}, \mathrm{nM}$ & $3,303 \pm 115$ & $2,024 \pm 110^{\mathrm{b}}$ & $3,702 \pm 177^{a}$ & NA & NA & NA \\
\hline \multicolumn{7}{|l|}{ Distal } \\
\hline $\mathrm{E}_{\max }, \% \mathrm{~T}_{\mathrm{K}}$ & $130.7 \pm 5.7(n=11)$ & $108.1 \pm 3.7^{\mathrm{a}}(\mathrm{n}=21)$ & $8.6 \pm 1.3^{\mathrm{a}, \mathrm{b}}(\mathrm{n}=15)$ & $4.3 \pm 0.7^{b}(\mathrm{n}=7)$ & $4.0 \pm 1.5^{\mathrm{b}}(\mathrm{n}=8)$ & $0.6 \pm 0.7^{\mathrm{b}}(\mathrm{n}=7)$ \\
\hline
\end{tabular}

Data are presented as means \pm SEM. ${ }^{\mathrm{a}} \mathrm{p}<0.05$ between segment type. ${ }^{\mathrm{b}} \mathrm{p}<0.055$-HT receptor subtype agonist vs. to 5 -HT. NA $=$ Not applicable.

Preincubation of distal or proximal OA segments with $100 \mathrm{nM}$ ketanserin (5- $\mathrm{HT}_{2}$ receptor antagonist) completely inhibited the contractile responses to $5-\mathrm{HT}$ and a- $\mathrm{CH}_{3}-5-\mathrm{HT}$ (table 3). Additionally, a bolus dose of 5-HT $(10 \mu \mathrm{M})$ was administered to observe the effects of acetyl- choline on endothelial function (online suppl. fig. 1), however these bolus doses highlighted the differences between distal and proximal segments (online suppl. table 1) compared with maximal responses from concentration-response curves. 
The 5- $\mathrm{HT}_{1 \mathrm{~A}}$ receptor agonist, 8-OH-DPAT (1 nM to $10 \mu \mathrm{M})$, elicited small, yet significant contractile responses in all OA segments at the highest concentration used, and distal segments had significantly higher maximal responses than proximal segments (distal segment $\mathrm{E}_{\max }$ : $8.6 \pm 1.3 \% \mathrm{~T}_{\mathrm{K}}$ and proximal segment $\mathrm{E}_{\max }: 5.7 \pm 1.4 \% \mathrm{~T}_{\mathrm{K}}$, $\mathrm{n}=15$ for both; online suppl. fig. 1D). In separate experiments, ( $n=3 /$ segment/inhibitor concentration), preincubation of myograph baths with either $100 \mathrm{nM}$ or $1 \mu \mathrm{M}$ of the selective and potent $5-\mathrm{HT}_{1 \mathrm{~A}}$ receptor antagonist, NAN-190, did not inhibit the minimal contractile responses observed by 8-OH-DPAT (data not shown). However, preincubation with ketanserin $(100 \mathrm{nM}) \mathrm{com}$ pletely abolished the contractile responses to $8-\mathrm{OH}$ DPAT in both segment types (table 3 ). The $5-\mathrm{HT}_{1 \mathrm{~B} / 1 \mathrm{D}}$ receptor agonist, sumatriptan ( $1 \mathrm{nM}$ to $10 \mu \mathrm{M})$, did not elicit any change in tone in either distal or proximal OA segments (data not shown).

\section{Discussion}

The OA isolated from the rats used in this study were approximately $4 \mathrm{~mm}$ in length, and since vessels $2 \mathrm{~mm}$ in length are suitable for small vessel myography [6], our initial rationale for bisecting the OA was to increase the number of vessels that could be studied from each rat. However, this approach led to the serendipitous finding that the contractile properties of OA segments appear to change significantly from the ECA to the NG, depending on the agonist under investigation. Specifically, we determined that distal OA segments contract to a significantly greater degree than proximal segments when exposed to vasopressin, the $\mathrm{V}_{1}$ receptor agonist, $\left(\mathrm{Phe}^{2}, \mathrm{Ile}^{3}, \mathrm{Orn}^{8}\right)$ vasopressin, and the $5-\mathrm{HT}_{2}$ receptor agonist, $\alpha-\mathrm{CH}_{3}-5$ HT. Moreover, distal segments of the OA were also more sensitive, with regard to $\mathrm{EC}_{50}$ values, to $\left(\mathrm{Phe}^{2}, \mathrm{Ile}^{3}, \mathrm{Orn}^{8}\right)$ vasopressin, 5-HT and $\alpha-\mathrm{CH}_{3}-5-\mathrm{HT}$. Although tachyphylaxis was observed in second round concentrationresponse curves for AT- and vasopressin-induced constrictions, vasopressin maintained this unique segmental vasoconstriction, albeit reduced. However, a second response curve for AT elicited no contractile response at any dose. Interestingly, a second response curve for 5-HT elicited almost identical maximal responses (data not shown) compared with first round concentration-response curves $(\mathrm{p}>0.05)$.

In the present study, the sensitivity of OA segments to AT was similar to those reported for other vessel types (e.g. rat thoracic aorta [11] and mouse abdominal aorta

Contractile Properties of the Occipital Artery
[12]), however it should be noted that comparing OA AT sensitivity and maximal contractions in this study to either vasopressin and/or 5-HT needs further experimentation as $\mathrm{AT}$ tachyphylaxis due to rapid $\mathrm{AT}_{1}$ receptor internalization has been reported $[8,9]$ and therefore may be a reflection of a reduced maximal response and subsequently a lower $\mathrm{EC}_{50}$ value. The complete inhibition of AT-mediated contractions in OA by losartan coupled with the lack of effect of the $\mathrm{AT}_{2}$ receptor agonist CPG-42112A are consistent with AT-induced contractions of the $\mathrm{OA}$ being mediated via activation of $\mathrm{AT}_{1}$ receptors. While activation of $\mathrm{AT}_{2}$ receptors has been reported to elicit vasodilation in other vessel types via the production of endothelium-derived relaxing factors [13], addition of CPG-42112A to OA preconstricted with $\mathrm{PGF}_{2 \alpha}$ had no effect on OA tone in the present study (data not shown). Additionally, in separate experiments, the development of tachyphylaxis to the vasoconstrictor effects of AT on isolated OA may have important biological implications, however further experiments in separate OA tissues are needed in order to generate a cumulative concentration-response curve from individual bolus doses and thus may elucidate in vivo sensitivity of OA to AT II.

Although the data demonstrate that endogenous AT plasma concentrations in control rats are approximately $100 \mathrm{pg} / \mathrm{ml}$ [14], this concentration (100 pM) elicited no observable constriction in our isolated OA arteries. These data may also elucidate the changes in OA constriction and flow in disease. For example, pulsatile tinnitus, secondary to stenotic lesions of the carotid artery, has been associated with reversal of flow in the OA. Additionally, abnormally high flow in the OA has led to pulsatile tinnitus [15]. Therefore, acutely one would assume high levels of AT would cause increased AT-dependent vasoconstriction, however chronically high levels of circulating AT may blunt a potentially important in vivo response of inhibiting increased blood flow to the OA.

Distal OA segments constricted to a significantly higher degree than proximal segments when exposed to vasopressin or the $\mathrm{V}_{1}$ receptor agonist, $\left(\mathrm{Phe}^{2}, \mathrm{Ile}^{3}, \mathrm{Orn}^{8}\right)$-vasopressin. Distal segments were also significantly more sensitive to $\left(\mathrm{Phe}^{2}, \mathrm{Ile}^{3}, \mathrm{Orn}^{8}\right)$-vasopressin than proximal segments, though this difference was not apparent when vasopressin was used as the agonist. However, $\mathrm{EC}_{50}$ values for vasopressin were significantly lower than $\mathrm{EC}_{50}$ values for $\left(\mathrm{Phe}^{2}, \mathrm{Ile}^{3}, \mathrm{Orn}^{8}\right)$-vasopressin and were similar to those reported for rat aorta, and mesenteric and tail arteries $[11,16]$. Vasopressin-induced contractions were blocked by the $\mathrm{V}_{1}$ receptor antagonist, $\mathrm{d}\left(\mathrm{CH}_{2}\right)_{5} \mathrm{Tyr}(\mathrm{Me})$ 
AVP, whereas the $V_{2}$ receptor agonist, desmopressin, elicited no significant change in OA segments either from baseline or in the presence of $\mathrm{PGF}_{2 \alpha}$-induced preconstriction (data not shown). Although it should be noted that total blood flow through the OA would be equally reduced regardless of which segment under investigation constricts, the unique finding that distal segments, regardless of bolus, first and second round concentrationresponse curve experiments, constrict to a much higher degree than proximal segments was only observable in vasopressin-induced constriction of the OA.

It is well established that the vasoactive effects of $5-\mathrm{HT}$ are predominantly mediated via the activation of $5-\mathrm{HT}_{1}$ and $5-\mathrm{HT}_{2}$ receptors [17]. In the present study, both distal and proximal OA segments constricted robustly when exposed to either $5-\mathrm{HT}$ or the $5-\mathrm{HT}_{2}$ receptor agonist $\alpha-\mathrm{CH}_{3}-5-\mathrm{HT}$. While distal segments were significantly more sensitive to either $5-\mathrm{HT}$ or $\alpha-\mathrm{CH}_{3}-5$ HT than proximal segments, contractile responses in both segment types were completely inhibited by the $5-\mathrm{HT}_{2}$ receptor antagonist, ketanserin $(100 \mathrm{nM})$. In contrast to $5-\mathrm{HT}_{2}$ stimulation, the $5-\mathrm{HT}_{1 \mathrm{~A}}$ receptor agonist, 8-OH-DPAT, elicited only weak contractions in OA segments, and even then only at the highest concentration used $(10 \mu \mathrm{M})$. The lack of constrictor effects of nanomolar concentrations of 8-OH-DPAT and the blockade of the small contractile response to 8-OH-DPAT by ketanserin, but not by the $5-\mathrm{HT}_{1 \mathrm{~A}}$ receptor antagonist, NAN190 , are consistent with the reported effects of $8-\mathrm{OH}-$ DPAT in rat coronary [18] and caudal [19] arteries, however this has been explained by the possibility that 8-OH-DPAT may be activating $5-\mathrm{HT}_{2}$ receptors at higher concentrations [18]. Since the $5-\mathrm{HT}_{1 \mathrm{~B} / 1 \mathrm{D}}$ receptor agonist, sumatriptan, did not have any effect on tone in OA, the results of the present study are consistent with $5-\mathrm{HT}_{2}$ receptors being the predominant $5-\mathrm{HT}$ receptor subtype in OA of the rat, which is a common finding for a variety of rat blood vessel types [18, 20,21]. However, of note, in isolated OA rings from humans, 5-HT-induced constrictions were mediated via $5-\mathrm{HT}_{1 \mathrm{~B}}$ and $5-\mathrm{HT}_{2 \mathrm{~A}}$ receptors at low and high concentrations of 5-HT [3]. The presence of a functional $5-\mathrm{HT}_{1 \mathrm{~B}}$ receptor was not detected in the data presented here, as demonstrated by the lack of constriction or dilation of rat OA to sumatriptan at resting tension or in $\mathrm{OA}$ preconstricted with $\mathrm{PGF}_{2 \alpha}$. The presence of $5-\mathrm{HT}_{1 \mathrm{~B}}$ receptors was verified via mRNA expression levels by Verheggen et al. [3], however our lack of functional $5-\mathrm{HT}_{1 \mathrm{~B}}$ receptors may be a result of an anesthetic- or species-dependent response. Although further studies to determine the vasoreactiv- ity of OA from healthy, non-anesthetized treated individuals may be of great importance it may be moot as this would be nearly impossible to collect. In this initial study, we determined that OA were significantly more sensitive to vasopressin $\left(\mathrm{EC}_{50}\right.$ values $\left.>10 \mathrm{nM}\right)$ compared with 5-HT ( EC $_{50}$ values $~ 1,000-3,000 \mathrm{nM}$ ), vasopressin compared to the $\mathrm{V}_{1}$ receptor agonist, $\left(\mathrm{Phe}^{2}, \mathrm{Ile}^{3}, \mathrm{Orn}^{8}\right)$ vasopressin, and the $5-\mathrm{HT}_{2}$ receptor agonist, $\alpha-\mathrm{CH}_{3}-5-$ $\mathrm{HT}$, compared with 5-HT. Additionally, the level of OA sensitivity to $\mathrm{AT}$ needs further elucidation as the $\mathrm{EC}_{50}$ values reported here may be diminished as a result of repetitive applications from a concentration-response curve rather than from separate bolus dose applications in separate tissues.

In summary, the present study is the first to characterize the contractile responses of OA isolated from the rat to AT, vasopressin and 5-HT, which appear to be mediated by $\mathrm{AT}_{1}, \mathrm{~V}_{1}$ and $5-\mathrm{HT}_{2}$ receptors, respectively. The observed difference in the reactivity of distal OA segments compared to proximal OA segments was an unexpected finding as our rationale for bisecting the OA was to increase the number of artery segments that could be studied from each rat. Further studies are warranted to investigate the potential significance of these differences in health and disease. In contrast, these differences may just be a reflection of changes in smooth muscle reactivity between the 'conduit' and 'microcirculation' ends of the OA. As such, immunohistochemistry studies may highlight the differences in sensitivity along the length of such a small vessel as a result of receptor density, however this may be due to the differences in vessel diameter (distal segments: $\sim 323.5 \pm 11.6 \mu \mathrm{m}$ and proximal segments: $\sim 435.1 \pm 8.9 \mu \mathrm{m}, \mathrm{n}=8$ for both). Even so, Miller et al. [22] demonstrated that agonist-stimulated splice variants of the glycine receptor $2 \alpha$ express differential sensitivity in transfected HEK cells. Therefore, these data demonstrate the unique differences in OA reactivity along the length of a potentially important blood vessel. As such, the significance of OA reactivity at distal and proximal segments of the OA will greatly benefit future studies to determine whether the function of this potentially important blood vessel changes in disease. It is hoped that this initial characterization of the OA will provide a basis for such studies.

\section{Acknowledgment}

Funding for this study was provided by the National Institutes of Health (1RO1NS054117-01A2, to Lewis and Robertson). 


\section{References}

$>1$ Lacolley P, Owen J, Sandock K, et al: Occipital artery injections of 5-HT may directly activate the cell bodies of vagal and glossopharyngeal afferent cell bodies in the rat. Neuroscience 2006;143:289-308.

$>2$ Jacobs L, Comroe JH Jr: Reflex apnea, bradycardia, and hypotension produced by serotonin and phenyldiguanide acting on the nodose ganglia of the cat. Circ Res 1971;29:145155.

$>3$ Verheggen R, Meier A, Werner I, Wienekamp A, Kruschat T, Brattelid T, Levy FO, Kaumann A: Functional 5-HT receptors in human occipital artery. Naunyn Schmiedebergs Arch Pharmacol 2004;369:391-401.

4 Hart JL, Jing M, Bina S, Freas W, Van Dyke RA, Muldoon SM: Effects of halothane on EDRF/cGMP-mediated vascular smooth muscle relaxations. Anesthesiology 1993;79: 323-331.

$\checkmark 5$ Rich GF, Roos CM, Anderson SM, Daugherty MO, Uncles DR: Direct effects of intravenous anesthetics on pulmonary vascular resistance in the isolated rat lung. Anesth Analg 1994;78: 961-966.

-6 Mulvany MJ, Halpern W: Contractile properties of small arterial resistance vessels in spontaneously hypertensive and normotensive rats. Circ Res 1977;41:19-26.

7 Robertson T, Hague D, Aaronson P, Ward J: Voltage-independent calcium entry in hypoxic pulmonary vasoconstriction of intrapulmonary arteries of the rat. J Physiol (Lond) 2000;525:669-680.
-8 Linder AE, Thakali KM, Thompson JM, Watts SW, Webb RC, Leite R: Methyl- $\beta$ cyclodextrin prevents angiotensin II-induced tachyphylactic contractile responses in rat aorta. J Pharmacol Exp Ther 2007;323:78-84.

$>9$ Holloway AC, Qian H, Pipolo L, et al: Sidechain substitutions within angiotensin II reveal different requirements for signaling, internalization, and phosphorylation of type $1 \mathrm{~A}$ angiotensin receptors. Mol Pharmacol 2002; 61:768-777.

10 Hamel C, Millette E, Lamontagne D: Role of nitric oxide and protein kinase $\mathrm{C}$ in the tachyphylaxis to vasopressin in the rat aortic ring. Life Sci 2005;77:1069-1081.

11 Chen L, McNeill JR, Wilson TW, Gopalakrishnan V: Differential effects of phosphoramidon on contractile responses to angiotensin II in rat blood vessels. Br J Pharmacol 1995;114:1599-1604.

12 Zhou Y, Dirksen WP, Babu GJ, Periasamy M: Differential vasoconstrictions induced by angiotensin II: role of AT1 and AT2 receptors in isolated C57BL/6J mouse blood vessels. Am J Physiol Heart Circy Physiol 2003;285:H2797H2803.

13 Paul M, Mehr AP, Kreutz R: Physiology of local renin-angiotensin systems. Physiol Rev 2006;86:747-803.

14 Huang H, Baussant T, Reade R, Michel JB, Corvol P: Measurement of angiotensin II concentration in rat plasma: pathophysiological applications. Clin Exp Hypertens A 1989;11: 1535-1548.

$\checkmark 15$ Cowley PO, Jones R, Tuch P, McAuliffe W: Pulsatile tinnitus from reversal of flow in an aberrant occipital artery: resolved after carotid artery stenting. AJNR Am J Neuroradiol 2009;30:995-997.
16 Dewachter P, Emala CW: Pre-exposure to vasopressin potentiates the vasoconstrictive effect of epinephrine in rat aorta isolated during late anaphylaxis. Shock 2010;33:655661.

17 Hoyer D, Hannon JP, Martin GR: Molecular, pharmacological and functional diversity of 5-HT receptors. Pharmacol Biochem Behav 2002;71:533-554.

18 Lai FM, Tanikella T, Cervoni P: Characterization of serotonin receptors in isolated rat intramyocardial coronary artery. J Pharmacol Exp Ther 1991;256:164-168.

19 Craig DA, Martin GR: 5-HT1B receptors mediate potent contractile responses to $5-\mathrm{HT}$ in rat caudal artery. Br J Pharmacol 1993;109: 609-611.

20 Luo G, Xu CB, Cao YX, Edvinsson L: Transcriptional up-regulation in expression of 5 hydroxytryptamine $2 \mathrm{~A}$ and transcriptional down-regulation of angiotensin II type 1 receptors during organ culture of rat mesenteric artery. Basic Clin Pharmacol Toxicol 2004; 95:280-287.

21 Rizzoni D, Perlini S, Mircoli L, et al: Enhanced vascular reactivity in the sympathectomized rat: studies in vivo and in small isolated resistance arteries. J Hypertens 2000;18:10411049.

22 Miller PS, Harvey RJ, Smart TG: Differential agonist sensitivity of glycine receptor $\alpha 2$ subunit splice variants. Br J Pharmacol 2004;143: 19-26. 